
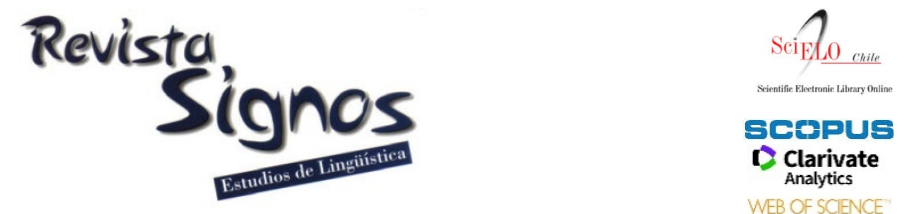

\title{
The learning and teaching of Spanish as a heritage language through community service- learning in New York City*
}

\author{
Aprendizaje y enseñanza de español como lengua de berencia \\ mediante el aprendizaje-servicio comunitario en la ciudad de \\ Nueva York
}

Francisco Salgado-Robles

COLLEGE OF STATEN ISLAND (CUNY)

UNITED STATES

francisco.salgado@csi.cuny.edu

\author{
Edwin M. Lamboy \\ City COLLEGE OF NeW YORK (CUNY) \\ UNITED STATES \\ elamboy@ccny.cuny.edu
}

Recibido: $27-\mathrm{II}-2018$ / Aceptado: $15-\mathrm{X}-2018$
DOI: $10.4067 / \mathrm{S} 0718-09342019000301055$

\begin{abstract}
This study explores the effects of the implementation of a community service-learning component in a foreign language teaching methodology course. Participants $(N=21)$, all heritage speakers of Spanish, were pre-service 7-12 Spanish teachers at two middlesized, public postsecondary institutions in New York City. As part of their community engagement experience, participants selected a site from a list of middle and high schools where they would get the opportunity to work with heritage learners of Spanish. Throughout the semester, they had to identify classroom needs, select one of those needs, develop an action plan to address that specific need, and finally reflect on the impact of their intervention on student learning and on their own professional, academic, and linguistic growth. At the end of the semester they completed a postcommunity service-learning survey consisting of 27 statements and 5 open-ended questions. The results show that the experience helped participants gain a better understanding of the teaching profession and how to become more involved in education. Moreover, it allowed participants to see how course content could be applied to the teaching of Spanish. Conversely, results do not show a direct effect on how pre-service teachers view their identities as Hispanics/Latinos and as speakers of Spanish. The study concludes with pedagogical implications for heritage language instruction and the implementation of further community service-learning in languages for specific purposes and proposes directions for future research.
\end{abstract}

Key Words: Spanish as a heritage language, service-learning, language for specific purposes, pre-service teacher training, foreign language teacher education. 


\section{Resumen}

Este estudio explora los efectos de la implementación de un componente de participación comunitaria en un curso de metodología de enseñanza de lenguas extranjeras. Los participantes $(N=21)$, hablantes de español como lengua heredada, eran profesores de español en formación inicial de educación secundaria en dos universidades públicas y de tamaño medio en la Ciudad de Nueva York. Como parte de su participación comunitaria, los participantes seleccionaron una escuela de una lista de escuelas intermedias y secundarias donde tendrían la oportunidad de trabajar con aprendices de español como lengua heredada. A través del semestre, tuvieron que identificar necesidades en el aula de clase, seleccionar una de esas necesidades, diseñar un plan de acción para atender esa necesidad específica y reflexionar sobre el efecto de su intervención en el aprendizaje de los estudiantes y en su autocrecimiento profesional, académico y lingüístico. Al final del semestre, llenaron un cuestionario que consistía en 27 aseveraciones y 5 preguntas abiertas. Los resultados muestran que esta experiencia ayudó a que los participantes desarrollaran un mejor entendimiento de la carrera docente y de cómo involucrarse más en la educación. Además, ésta contribuyó a que los participantes aprendieran a aplicar el contenido del curso a la enseñanza del español. Por el contrario, los resultados no muestran un efecto directo en cómo los futuros profesores ven su identidad hispana/latina o como hablante de español. El estudio concluye con implicaciones pedagógicas para la enseñanza de lenguas de herencia y la implementación de un mayor aprendizaje-servicio en la comunidad en lenguas para fines específicos y propone direcciones para futuras investigaciones.

Palabras Clave: Español como lengua de herencia, aprendizaje-servicio, lengua con fines específicos, formación inicial de profesores, formación de profesores de lengua extranjera.

\section{INTRODUCTION}

The fields of languages for specific purposes (LSP) and community servicelearning (CSL) have gained considerable popularity in US higher education over the last twenty years (Long \& Uscinski, 2012; Lafford, Abbott \& Lear, 2014; SánchezLópez, Long \& Lafford, 2017). Most of the research thus far has examined the potential impact of both disciplines on second language (L2) learners (e.g., Lafford, 2012; Lamboy \& Thompson, 2012; Lear, 2012; Sánchez-López, 2013; Abbott, 2017; Salgado-Robles \& Kirven, in press; just to name a few). Despite the growing interest in these areas, little is known about the effect of LSP and CSL on heritage language (HL) learners, particularly as it relates to language proficiency and HL pedagogy (e.g., Pino, 2001; Angelelli \& Degueldre, 2002; Martínez, 2010; Martínez \& Schwartz, 2012; King de Ramírez, 2017; Ruggiero, 2018; Martínez \& San Martín, 2018). This study delves into the interface between the learning and teaching of Spanish as a HL through CSL.

Based on Martínez and San Martín's (2018) framework, HL learning for the professions is an innovative approach to language teaching that merges methodological approaches from LSP, HL education, and CSL to produce advanced, 
targeted language proficiency and contextualized understanding of the education issues surrounding the teaching of Latinos in the US, as represented in Figure 1.

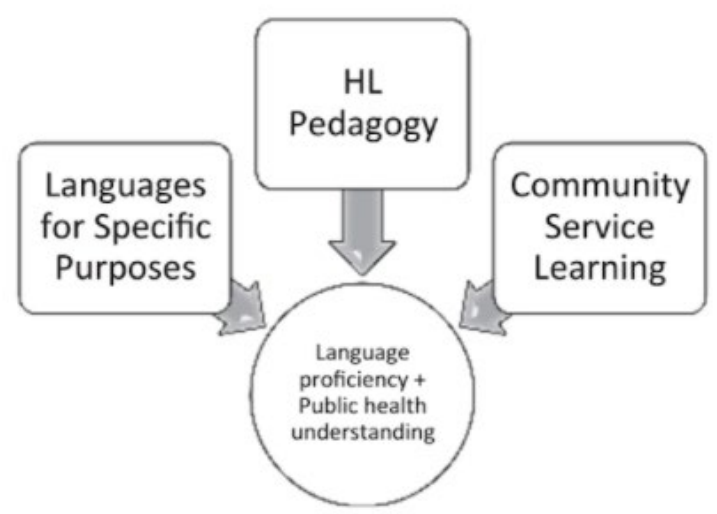

Figure 1. Pedagogical foundations of HL learning for the health professions.

In the Martínez and San Martín (2018: 111) words, this model:

"consists of developing medical discourses across linguistic and multimodal genres with the intent of developing a high degree of flexibility in the sociolinguistic repertoire of the learner"

\section{Literature review}

This section discusses literature review of recent scholarship on the main areas of study related to the core topic of the current article. While research on HL learners and pedagogy, CSL, and LSP is first presented alone, the last part, conversely, connects this group of language learners, the community-engagement, and the academic disciplines and content domains -i.e., Spanish for the professions (e.g., business, healthcare, interpretation, law, social work, translation, etc.).

\subsection{HL learners and education}

The term 'heritage learner' has been quite controversial. One of the most commonly referenced definitions is the one proposed by Valdés (2001: 38), i.e.,

"a language student who is raised in a home where a non-English language is spoken, who speaks or at least understands the language, and who is to some degree bilingual in that language and in English".

This definition highlights the role of exposure to a language other than English in the home setting and the resulting heritage language-English bilingualism, which varies significantly from individual to individual. Later attempts to provide a more functional definition that could be applied to practical pedagogical approaches, on one hand, and 
that could foster a deep understanding of the fundamental characteristics of heritage learners, on the other hand, have been openly and widely contested (García, 2005; Polinsky \& Kagen, 2007). Nonetheless, scholars do agree that members of this population show a wide range of linguistic and cultural competencies, which presents unique challenges to teachers and educators, both in L2 and HL classes.

The greatest difference amongst HL and L2 learners relates to the contact they have had with the language. Whilst the majority of L2 learners have had contact with the language mainly through formal instructional settings (e.g., school), HL learners, conversely, have grown up hearing or using the language in a natural context, such as in the home or community. Age, learning context, language variety, connections to the language, connection to the culture, and language proficiency are the categories that have been found to distinguish one from the other.

In the education arena, some scholars have asserted that well-implemented differentiation strategies may be enough to support these learners and provide them with the opportunity to improve their language skills in a 'traditional' FL classroom. However, others have called for the creation of language classes exclusively designed for the HL population (Beaudrie, Ducar \& Potowski, 2014; Fairclough \& Beaudrie, 2016, inter alia). Some of the arguments in favor of the latter include the level of anxiety that non-native speakers of a language experience when they are in a classroom with more advanced, 'native' speakers of the language, and the frustration that HL speakers feel in language classes that they consider too basic.

\subsection{CSL}

CSL arose from the tenets of experiential education and constructivist theories that advocate for learning through first-hand discovery (Furco, 2001). The defining characteristic that sets CSL apart from other types of volunteer or internship endeavors is that students' service experiences are tied to the academic content of an on-campus course or curriculum (Giles, Honnet \& Migliore, 1991). As stated by Jacoby (1996), CSL is "experiential education that engages students in activities that address human and community needs together with structured opportunities" Jacoby, 1996: 5). In the past few decades many post-secondary instructors in the United States have included CSL into their classes (Sánchez-López, 2013), since this type of handson pedagogy provides students the opportunity to reflect on their involvement in their service, facilitating a deeper understanding academic content and community awareness (Knouse \& Salgado-Robles, 2015). Furthermore, the CLS methodology comes with multiple benefits for all involved parties, including students, faculty, the institution, and the community. 


\subsection{LSP}

According to Byram and Hu (2013), LSP is defined as "the teaching of second and foreign languages with the aim of helping learners enter or make progress in a particular area of work or field of study" (Byram \& Hu, 2013: 391). The interdisciplinary field of LSP, which has steadily gained popularity in higher education in the US over the past two decades, has proved to be effective in providing studentcentered elements and attracting students. Moreover, based on the 2007 report of the Ad Hoc Committee on Foreign Languages of the American Modern Language Association, the goals of foreign language education at the college level are redefined in accordance with the increasingly interconnected world which our students are being prepared to enter. That is,

"the language major should be structured to produce a specific outcome: educated speakers who have deep translingual and transcultural competence" (Ad Hoc Committee on Foreign Languages of the American Modern Language Association, 2007: 237).

It can be argued that LSP provides ample opportunities for learners to develop this competence. Similarly, from a multidisciplinary curricular design and research angle, LSP courses have also been vital not only to attract students who want to learn a language for its value in their future careers, but also to overcome the decline in enrollment and resulting budget cuts through which many language programs across the nation are navigating. In Gerndt's (2012: 6) words, "LSP diversifies the tradition of literature-only courses and provides a practical approach to language learning".

\subsection{Research on Spanish HL education, CSL, and LSP}

Although a plethora of research has examined issues regarding Spanish HL education, CSL, and LSP separately, fewer studies have focused on the point of intersection between these three fields. To our knowledge, the exceptions are Pino (2001), Angelelli and Degueldre (2002), Martínez (2010), Martínez and Schwartz (2012), King de Ramírez (2017), Martínez and San Martín (2018), and Ruggiero (2018).

Specifically, Pino (2001) discovers professional gains made by HL learners enrolled in a course on Spanish for business professionals, such as researching foreign business models, demonstrating cultural competency, and practicing professional linguistic registers. Angelelli and Degueldre (2002), on the other hand, describe the successes and challenges in developing courses that allow students to develop skills in using the target language within professional contexts. Not only does this study raise HL students' awareness of the difference between language for communication and language for work through an intensive superior-level language/skill course for teachers, translators, and interpreters, but it also provides them with tools to enhance 
their language skills in order to work with them. Martínez (2010) reports a project designed to prepare future healthcare professionals with advanced Spanish language skills and develop their awareness of language-related issues in the healthcare field. As result of working toward a common objective and fulfilling an identified community need, this program helps participants improve their communication skills in healthcare settings in the Spanish-speaking community. Martínez and Schwartz (2012) study a CSL experience conducted with medical Spanish students at the advance level. To that end, the authors examine the results of a questionnaire focused on their HL students' Spanish knowledge base, together with their understanding and appreciation of Spanish language variants, following a 15-hour mini-internship experience in a local health clinic. Martínez and Schwartz (2012) come to the conclusion that students increase their bilingual range from their participation in the internship experience by exploring new vocabulary, applying background knowledge from other subject areas, and learning how to translate across language varieties to increase patients' understanding of medical conditions. As authors point out,

"Community engagement provides students with a level of motivation and investment in language learning that would be difficult to achieve in a classroom setting alone" (Martínez \& Schwartz, 2012: 46).

King de Ramírez (2017) finds that a professional community internship course indeed serves the linguistic (e.g., written and oral skills) and social (e.g., awareness of immigration policy) needs of HL learners to the degree that this novel approach may be an alternative to HL-specific language courses. In addition, through a thorough digital storytelling project, Martínez and Martín (2018) conclude that HL learners in health science degree programs experience not only significant personal and professional growth, but also sociolinguistic gains. Lastly, in Ruggiero (2018), HL students are required to collaboratively design and support self-sustaining microeconomies centered on the arts (e.g., accessory design, fashion, music, and visual arts). Results show that participants increase their self-esteem and self-confidence in Spanish language skills and in their collaborative and interactional abilities. Results also point to a higher degree of cultural sensitivity and cultural identity.

As evidenced by the summary above, this paper addresses a very specific need in the fields of HL education, CSL, and LSP. It focuses on the preparation of future teachers of Spanish who are HL speakers themselves and who will more likely than not work with HL learners in a diverse urban setting. Particularly, the goal of this study is to determine the effect of the implementation of a CSL component in a teaching methods course on future Spanish teachers' understanding of the needs of HL, their own Spanish-speaker identity, and their professional and personal development. What makes this study unique is the fact that it focuses on CSL in a context in which heritage speakers teach HL and the effects on both groups of individuals. 
The next section presents our research questions, followed by a description of the methodology employed. The last two sections provide a detailed analysis of the results, a discussion of the study's conclusions and limitations, and suggestions for future research.

\section{Research questions}

In wishing to explore how future teachers of Spanish can be better prepared, we examined the following research questions:

(1) How can CSL help prepare future teachers of Spanish to work with HL populations in public schools?

(2) How can participants be provided with an understanding of the specific linguistic and cultural needs of HL learners of Spanish in the United States?

(3) How can a series of CSL experiences be coordinated in order to give them the chance to connect with HL learners and plan and deliver "teaching moments" to support these individuals' linguistic growth?

(4) What effect would a CSL experience working with HL learners have on a future Spanish teacher's professional and personal growth, and Spanish-speaker identity?

\section{Methodology}

\subsection{Context of the study and participants}

During the course of a regular semester, twenty-one HL students in a Spanish education program from two different campuses of a large university in New York City were invited to participate in this study. These students were enrolled in a foreign language teaching methodology course required for an academic degree leading to New York State certification to teach Spanish in grades 7th to 12th. Participation in the study involved completion of the 30-to-35-hour CSL project in one of the sites identified by the instructors (i.e., schools located in four of the five boroughs of New York City), four checkpoint reports, and a post-CSL survey (a modified version from Thompson, 2013) with questions intended to gather data on opinions before, during, and after the CSL project (see Appendix 1 for a sample of the surveys). Qualitative and quantitative data were gathered from the post-CLS survey and are presented and discussed below.

Participants -i.e., teacher candidates (TC) - were HL speakers of Spanish from somewhat similar academic, sociolinguistic, and professional backgrounds. According to their pre-fieldwork survey, all of the participants were undergraduate students in their junior or senior year at the university, were first-generation Americans, and were between the ages of twenty and twenty-seven. All participants had learned Spanish at home and used the language frequently to communicate with their family members. 
The survey also determined that none of the participants had formal teaching experience prior to this semester.

\subsection{Instruments and procedures}

The project involved three phases: assigning CSL sites (i.e., schools), collection of assignments, and collection of post-CSL surveys. These phases are explained next.

Phase I - Sites: TCs were given the opportunity to choose the site where they wanted to have their CSL experience from a list provided by the instructors. The lists of sites were different for convenience and because the campuses are located in different boroughs of the City of New York, as shown in Figure 2. Furthermore, TCs were made aware that the cooperating teachers (CTs) with whom they would be working in these sites were familiarized with the tenets of CSL and were willing to open their classrooms for them to take on the role of teacher.

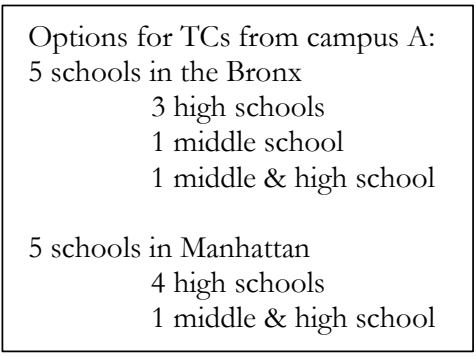

$$
\begin{aligned}
& \text { Options for TCs from campus B: } \\
& 4 \text { high schools in Staten Island } \\
& 1 \text { high school in Brooklyn } \\
& 1 \text { high school in Manhattan }
\end{aligned}
$$

Figure 2. Location of schools for the two participating campuses.

After selecting their sites, participants were asked to get the documentation needed to be able to start their CSL projects from the appropriate offices in their respective campuses. They were instructed to focus first on getting to know the schools, the CTs, and the students. At the same time, participants had to identify needs in the classroom. Some of the examples discussed in class included differentiated instruction, creating an engaging environment, working with groups of learners with specific academic needs or challenges, use of technology, and curriculum development.

Phase II - Assignments: Throughout the semester, TCs submitted four CSL project checkpoint reports:

(1) A general description of the school and the community where the CSL project was being conducted, including ethnic and/or racial distribution in the school and the community; school offerings; languages taught; school rating; and personal, cultural, and community assets of the students in the selected class. (Due by the fourth week of the semester.)

(2) A description of the need identified in the classroom, rationale for selecting this need, an action plan for the entire semester, and an explanation of how this intervention was expected to impact heritage speakers of Spanish. This had to 
be negotiated with and approved by the CT. (Due by the sixth week of the semester.)

(3) A progress report that explained what the TC had done so far and a reflection on the CSL experience and its impact on student learning. This report had to address both positive and challenging (if any) aspects of this experience. (Due by the tenth week of the semester.)

(4) A general assessment (reflection) of the TC's own personal experience in this classroom, an evaluation of the project's successes and challenges, and recommendations on how the identified need should be addressed in the future. (Due by the fourteenth week of the semester.)

Phase III - Post-CSL Survey: At the end of the semester, TCs completed a postCSL survey that invited them to reflect on:

(1) Their experience at the beginning of the semester - 5 statements (five-point scale);

(2) Their experience during the semester - 16 statements (five-point scale);

(3) The course and the entire CSL experience - 6 statements (five-point scale) and 5 open-ended questions.

\section{Data analysis and results}

The twenty-seven statements included in the post-CSL survey were phrased affirmatively. Therefore, the higher the response in the five-point scale, the more positive the attitude of the participants in relation to the behavior or opinion described in the statement. In the scale provided, $1=$ 'strongly disagree', $2=$ 'disagree', 3 = 'neither agree nor disagree', $4=$ 'agree', and $5=$ 'strongly agree'. Table 1 presents the mean averages of the responses to these statements. 
Table 1. Mean averages of the responses to the statements in the post-CL survey.

\begin{tabular}{|c|c|}
\hline Statements & Means \\
\hline 1. I knew what community service-learning was. & 3.77 \\
\hline $\begin{array}{l}\text { 2. The course objectives and how they related to the service-learning experience were clearly } \\
\text { stated in the syllabus. }\end{array}$ & 4.72 \\
\hline $\begin{array}{l}\text { 3. The course objectives and how they related to the service-learning experience were clearly } \\
\text { communicated by the professor. }\end{array}$ & 4.77 \\
\hline $\begin{array}{l}\text { 4. The course objectives and how they related to the service-learning experience were clearly } \\
\text { communicated by the community partner(s). }\end{array}$ & 3.61 \\
\hline 5. I was eager to begin my service-learning project. & 4.22 \\
\hline 6. The needs of the community partner(s) were clearly communicated to me. & 3.88 \\
\hline 7. There was adequate communication between the cooperating teacher and me. & 3.94 \\
\hline 8. There was adequate communication between the professor and me. & 4.88 \\
\hline 9. I felt I could contact the cooperating teacher if I had concerns. & 4.11 \\
\hline 10. I felt I could contact the professor if I had concerns. & 4.88 \\
\hline 11. The cooperating teacher provided me with guidance. & 4.11 \\
\hline 12. The cooperating teacher provided me with challenging and meaningful activities. & 4.05 \\
\hline 13. I took the time to understand the needs in the classroom. & 4.38 \\
\hline 14. In my work, I addressed the classroom need(s) I identified. & 4.50 \\
\hline 15. I took this project seriously. & 4.83 \\
\hline 16. The work I did increased my understanding of the nature of teaching. & 4.88 \\
\hline $\begin{array}{l}\text { 17. The work I did helped me see how the subject matter of the course can be applied to the } \\
\text { teaching of Spanish. }\end{array}$ & 4.61 \\
\hline $\begin{array}{l}\text { 18. The service aspect of this course showed me how I can become more involved in } \\
\text { education. }\end{array}$ & 4.72 \\
\hline 19. The service aspect of this course helped me become more aware of the needs of schools. & 4.72 \\
\hline 20. The service involved in this course benefited the students and the cooperating teacher. & 4.38 \\
\hline $\begin{array}{l}\text { 21. During my service I interacted with students from different social, economic, or ethnic } \\
\text { backgrounds. }\end{array}$ & 4.77 \\
\hline $\begin{array}{l}\text { 22. The service involved in this course helped me gain a clearer idea of my goal to become a } \\
\text { Spanish teacher. }\end{array}$ & 4.83 \\
\hline 23. The service I performed and the skills I developed helped make me a better future teacher. & 4.55 \\
\hline 24. The service experience complemented the learning objectives of the course. & 4.66 \\
\hline 25. The time needed to satisfy the service-learning component of this course was worthwhile. & 4.61 \\
\hline 26. The service-learning experience had a direct impact on my personal growth & 4.55 \\
\hline 27. The service-learning experience had a direct impact on my oral communication skills. & 4.55 \\
\hline
\end{tabular}

Graph 1 illustrates the means of the responses to statements 1 through 5, which relate to the participants' opinions at the beginning of the semester. The results show that most respondents already knew what CSL was (statement \#1), with a mean average of 3.77. They also demonstrate that the great majority of participants felt that the course objectives and how they related to the CSL experience were clearly stated in the syllabus (statement \#2) and clearly communicated by the instructors (statement \#3). On the other hand, they were not in strong agreement about course objectives and the CSL experience being clearly communicated by the CTs (statement \#4). The mean of the responses to this particular statement was 3.61, which highlights the importance of working together with teachers and community partners in general to make sure that the message students receive from both angles (i.e., instructors and teachers) is in sync and equally compelling. Finally, the great majority of participants 
indicated that they were enthusiastic about beginning their CSL projects (statement \#5).

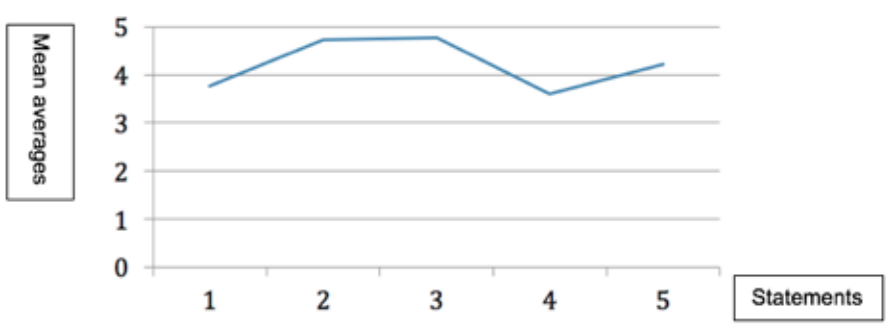

0: Not Applicable | 1: Strongly Disagree | 2: Disagree | 3: Neither Agree nor Disagree | 4: Agree | 5: Strongly Agree

Graph 1. Participants' experience at the beginning of the semester.

As described above, statements 6-21 invited participants to reflect on their CSL experiences. Results are illustrated in Graph 2. In general, these results clearly show that respondents had a very positive experience in regard to communication, guidance, classroom dynamics and needs, awareness of nature of the teaching and learning process, and involvement in their own learning as future teachers. For instance, the overwhelming majority of students in these courses expressed that there was adequate communication and openness with the college instructor (statements \#8 and \#10). They also indicated that the CSL project allowed them to interact with a diverse student population (statement \# 21) and that the experience was equally beneficial for the students they worked with, the CT (statement \#20), and themselves (statement \# 16).

Perhaps of more importance are the gains in terms of the pedagogical and dispositional growth we expect to see in future teachers. Specifically, participants engaged in an inquiry process that required observation, identification of needs, creation of an action plan, and execution of such plan (statements \#13, \#18, and \#19). The results suggest an increase in the participants' understanding of the nature of teaching (statement \#16), and, with greater significance, how to make meaningful connections between course content (i.e., Spanish for Education Professionals) and practice (statement \#17). That is one of the foundational goals of CSL: giving learners the opportunity to bridge the gap between theory and the real world.

The results of statements \#6, \#7, and \#9 merit some special attention. While the means obtained from the answers to these statements suggest that, overall, participants agreed, they indicated to us that we could have done more to make sure CTs communicated their classroom needs and realities more freely with participants. A more open and intentional communication would have made the inquiry process described above even richer and more pertinent. Also, the results of statement \#9 could possibly suggest that respondents needed or wanted more access to the CT. 
Given all the responsibilities that teachers have, and the fact that it is entirely up to them to make themselves available to students beyond the time they spend together in the classroom, we wonder how realistic it would have been on our part to expect better results.

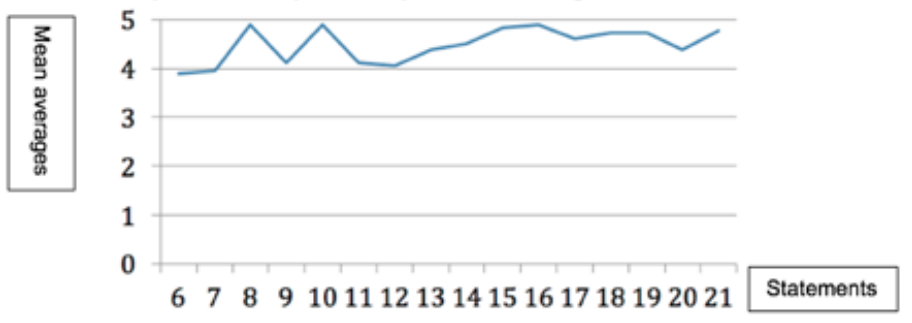

0: Not Applicable | 1: Strongly Disagree | 2: Disagree | 3: Neither Agree nor Disagree | 4: Agree | 5: Strongly Agree

Graph 2. Participants' experience during the semester.

Graph 3 illustrates the results for statements 22-27, which encouraged respondents to reflect on the course and the CSL experience. These outcomes confirm that the experience helped participants gain a better idea of their academic and professional goals (statement \#22) and helped prepare them for their future careers as educators (statement \#23). Furthermore, participants saw value in the experience in relation to their personal growth (statement \#26) and impact on their oral communication skills (statement \#27). Finally, from a pedagogical perspective, respondents indicated that their CSL project complemented the course learning objectives (statement \#24) and that the end results were worth the time investment (statement \#25).

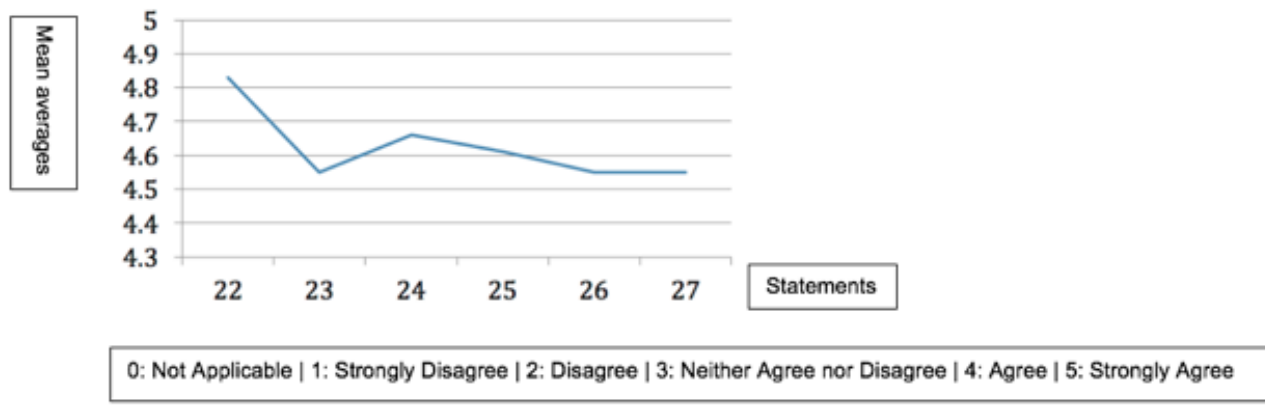

Graph 3. Course and the entire CSL experience.

The post-CSL survey also included five open-ended questions. Participants were not asked to give a numerical answer using the five-point scale or to provide a yes/no answer. The purpose of these questions was to have participants react to the statements in light of their CSL experiences. For instance, the first question (\#28 in the survey) explored the impact of the experience on their Hispanic/Latino identities. As expected, the answers varied significantly and did not point to a direct relationship 
between having worked with HLs and the future teacher's Hispanic/Latino identity. Among the answers, a participant highlighted the opportunity to learn from others and, in the process, discover oneself. Another one argued that teachers and students sometimes have different perspectives on what being Hispanic/Latino really is, which suggest some sort of ideological clash. Interestingly, many of the answers pointed to issues of identity without necessarily answering the question that was posed. For example, participants appreciated the opportunity to instill in others pride for being Hispanic/Latino and seeing an attitudinal change in their students. They also enjoyed using cultural skills to connect with their students, experiencing first-hand how the classroom reflects diversity in the community, and seeing how students demonstrate who they are as individuals in the classroom.

The second question (\#29) delved into the effect that the experience had on the participants' identity as Spanish speakers. A few of them singled out the ability to model academic Spanish and connect with students who speak the language as the most positive effect. Others said they felt personal satisfaction in knowing that the new generations are using Spanish and are interested in maintaining it. One particular participant said he appreciated the opportunity to see the role that the Spanish language plays in who he is and help others "make the connection." By contrast, a few participants mentioned the lack of interest in learning and using Spanish of some of their students and expressed concerns about these students' future language skills.

Questions \#30 and \#31 are of vital relevance to the focus of this study. The first one asked participants whether the CSL experience had helped them gain a better understanding of the needs of HL learners, while the second one, conversely, tried to gauge their ability to put strategies for the teaching of Spanish to HL learners into practice. The answers to the former hinted at the need to create language-rich classroom environments, offer classes specifically designed for HL learners, and be better prepared to differentiate instruction. Participants also learned about HL learners' different levels of proficiency and the positive effect that bilingual teachers who are heritage speakers of Spanish themselves may have on these learners. Conversely, some of the responses were not as positive and pointed to key issues that must be addressed in a methods course. For example, one of them mentioned the students' lack of motivation, but then added she thought they finally "got" the importance and benefits of being bilingual. Another one just pointed out that students simply did not want to learn and did not provide any evidence of reflecting on her own learning or on the meaning and implications of the students' lack of motivation.

In terms of the participants' ability to practice the strategies they were learning in the teaching methods course, the answers provided pointed to different results, despite having indicated that the experience complemented the learning objectives of the course (statement \#24). Most answers were vague and did not allow us to 
ascertain whether the CSL experience had actually translated into more opportunities to teach real students in a real classroom. Of those who had the opportunity to engage with students through teaching, some claimed to have had a fruitful learning experience. Others did not, primarily because of challenges presented by 'mixed' classes with students with varying linguistic abilities, including some labeled as HL learners but with no command of the language. In our opinion, both types of experiences are equally valuable, for these participants had the unique opportunity to become aware of and involved in the reality of foreign language teaching in New York City. Of equal importance and value is the fact that participants were able to face key challenges in the field, which presented them with a chance to begin thinking about ways in which they can become change agents and advocates for the teaching and learning of foreign languages. To us, this is as relevant as other more obvious goals we keep in mind as we strive to instill in our students a commitment to be leaders in their professional communities.

To conclude the survey, participants were asked to give suggestions to improve the CSL experience. The answers included not 'forcing' them to do CSL solely in sites pre-selected by the instructors, for location, traveling time, and juggling personal responsibilities may negatively impact the experience. Respondents also suggested requiring less hours, having a more active role in the classroom, and being able to work with more homogeneous classes. Some of the suggestions related specifically to CTs, such as making sure they really know what is expected of future teachers and asking them to engage future teachers more frequently in lesson planning. Nonetheless, there were two specific suggestions that we found quite telling and important for the work that we will do in the future. First, establishing stronger relationships between the college and schools. This is an ongoing process that requires purposeful and ongoing communication, nurturing, and evaluation. Finally, one participant indicated that, despite the fact that the CSL experience could undoubtedly be improved, he was glad that he had the opportunity to be exposed to the reality of the HL classroom. We consider that to be a huge accomplishment.

\section{CONCLUSIONS}

The purpose of this study was to assess the effects of a CSL project through which Spanish teachers-in-training who were heritage learners of the language had the opportunity to work for 30-35 hours during a regular semester with HL learners of Spanish in New York City public schools. As evidenced by the data obtained from a post-CSL survey, participants found that this was a fruitful experience for themselves, as well as for students and CTs. In particular, participants found that their involvement in this project provided them with a better understanding of the teaching profession. By engaging in it, they noticed why it is so important for teachers to consider such things as the classroom environment, the students' learning needs, and the diversity we find in an urban educational setting in their practice. This contributed 
to their growth as reflective practitioners. They also took notice of how essential it is to try out various strategies and approaches to attain a final goal. As a result, respondents reported that the service they provided and the skills they developed through the CSL experience showed them how they could become more involved in education and helped make them better future teachers (Lafford et al., 2014). Of equal relevance is the finding that the experience helped them define their individual professional goals.

Most of the education courses in teacher preparation programs offered in the United States have a fieldwork component that requires spending a set number of hours in a school, in most cases, or completing other types of assignments (e.g., conducting interviews and watching pre-selected videos that show exemplary teaching practices). For quite a long time now, academics, school systems, and policy makers have questioned the relevance of the tasks that future teachers do as they complete these fieldwork hours and have proposed alternatives that go beyond classroom observation in order to gradually give future teachers a more active and participatory role in schools, allowing for the development of a more clinically-rich curriculum. One of the goals of this study was to identify areas of research needs as defined by LSP scholars in US higher education. The present study suggests that reconceptualizing fieldwork requirements as CSL projects may help instructors address some of these concerns, while moving towards giving their students the opportunity to get more out of the courses. The findings demonstrate how CSL proved effective in enhancing pre-service teachers' pedagogical knowledge of instructional strategies for working with Spanish learners. Specifically, participants claimed that the work they did helped them see how course content could be applied to the teaching of Spanish. They also asserted that the experience complemented the learning objectives of the course, which may have had something to do with them gaining a clearer idea of their goal to become Spanish teachers.

In contrast, this study yielded inconclusive or varying results in other areas. First, some participants expressed having engaged in a process of discovery of their own Hispanic/Latino identities and having appreciated being able to help students connect to theirs. However, we later realized we had missed the opportunity to better prepare participants for this aspect of the CSL experience. For instance, we could have engaged them in a process of exploration of the topic of Hispanic/Latino identity per se, the factors that help shape this identity, and the multiple ways in which it is enacted and performed in daily life. In other words, the pre-CSL itself needed to include more deliberate steps to allow participants to consciously tackle this issue. Second, participants were very excited to be able to actually use all the Spanish they had learned in real-life situations. Some respondents claimed having enjoyed the chance to use a more formal, academic register of Spanish in the classroom, and having helped students gain a sense of appreciation for the study and maintenance of 
Spanish (cf. Lafford, 2012), but the results do not point to the CSL project having a direct impact on their identity as Spanish speakers. This is a new avenue that LSP scholars should further explore.

One of the main lessons we learned relates to the different types of experiences that participants had with their CTs, which resulted in different levels of involvement in the classrooms. Although the pre-selection of sites was based on relationships we had developed with CTs for at least a year and we believed that these CTs were fully aware of the goals of our programs and of the CSL project, some participants had a more productive and engaging experience than others. This points to the importance of intentional and continuous communication among all stakeholders, especially between instructor and CT. Particularly, for school-based CSL projects to be successful, it is imperative for CTs to understand that future teachers must have as many opportunities as possible to act as 'the teacher of record' in the classroom, the individual responsible for (co-)planning instruction, (co-)teaching, and (co-)managing the environment. Also, CTs must believe in the partnership ideas of CSL and create moments for the future teacher to test the waters, learn from mistakes, and evolve. We acknowledge that this is easier said than done, especially since CTs are the ones to be held accountable should anything affect their students' well-being and learning. Nonetheless, as Epstein and Ratner (2015: 116) argue, this type of project benefits the classroom teacher:

\footnotetext{
"as she can shape the candidates' work so that it meets the needs of her students ... while her students receive targeted assistance, often working directly with the candidates who have particular pedagogical ideas to put to use".
}

Nonetheless, we do not consider this to be a limitation of the study. When implementing CSL in a course, educators must expect their students to have a multiplicity of experiences, and consequently, a multiplicity of opinions and reactions to the reality they had to deal with. We must listen to and learn from their voices to not only make the CSL experience even better in the future, but also be able to help students gain a better understanding of the fields they will work in after they complete their degrees.

\section{REFERENCES}

Abbott, A. (2017). Civic engagement and community service learning: Connecting students' experiences to policy and advocacy. In M. Bloom \& C. Gascoigne (Eds.), Creating Experiential Learning Opportunities for Language Learners (pp. 3352). Bristol, UK: Multilingual Matters. 
Angelelli, C. \& Degueldre, C. (2002). Bridging the gap between language for general purposes and language for work: An intensive superior-level language/skill course for teachers, translators and interpreters. In B. L. Leaver \& B. Shekhtman (Eds.), From Advanced to Distinguished: Developing Professional-Level Language Proficiency (pp. 91-110). Cambridge, UK: Cambridge University Press.

Beaudrie, S. M., Ducar, C. \& Potowski, K. (2014). Heritage Language Teaching: Research and Practice. Columbus, OH: McGraw-Hill Education.

Byram, M. \& Hu, A. (Eds.) (2013). Routledge Encyclopedia of Language Teaching and Learning. London, UK: Routledge.

Epstein, S. E. \& Ratner, A. (2015). How can I help? Secondary education classrooms as sites for service and learning. Issues in Teacher Education, 24(2), 101-118.

Fairclough, M. \& Beaudrie, S. M. (Eds.). (2016). Innovative Strategies for Heritage Language Teaching: A Practical Guide for the Classroom. Washington, DC: Georgetown University Press.

Furco, A. (2001). Advancing service-learning at research universities. New directions for Higher Education Series, 114, 67-78.

García, O. (2005). Positioning heritage languages in the United States. Modern Language Journal, 89, 601-605.

Gerndt, J. L. M. (2012). Shifting the curriculum to language for specific purposes. Global Business Languages, 17(2), 3-15.

Giles, D., Honnet, E. P. \& Migliore, S. (1991). Research Agenda for Combining Service and Learning in the 1990s. Arlington, VA: National Society for Experiential Education.

Jacoby, B. (1996). Service-learning in today's higher education. In B. Jacoby \& Associates (Eds.), Service-Learning in Higher Education: Concepts and Practices (pp. 3-25). San Francisco, CA: Jossey-Bass.

King de Ramírez, C. (2017). Preparing students for the workplace: Heritage learners' experiences in professional community internships. In M. Long (Ed.), Language for Specific Purposes: Trends in Curriculum Development (pp. 55-72). Washington, DC: Georgetown University Press.

Knouse, S. M. \& Salgado-Robles, F. (2015). Expanding the community and enhancing the experience: The dual university model and web 2.0 technologies in a Spanish community service-learning course. Journal of Language Teaching and Learning, 5(2), 54-73. 
Lafford, B. A. (2012). Language for specific purposes in the United States in a global context: Commentary on Grosse and Voght (1991) revisited. The Modern Language Journal, 96, 1-27.

Lafford, B. A., Abbott, A. \& Lear, D. (2014). Spanish in the professions and in the community in the US. Journal of Spanish Language Teaching, 1(2), 171-186.

Lamboy, E. M. \& Thompson, G. (2012). Integrating classroom and community: Service-learning in the Spanish conversation class. MIFLC Review, 18, 113132.

Lear, D. (2012). Language for specific purposes curriculum creation and implementation in the service to the U. S. community. The Modern Language Journal, 96, 158-172.

Long, M. K. \& Uscinski, I. (2012). Evolution of languages for specific purposes programs in the United States: 1990-2011. The Modern Language Journal, 96, 173-189.

Martínez, G. (2010). Medical Spanish for heritage learners: A prescription to improve the health of Spanish-speaking communities. In S. River-Mills \& J. A. Trujillo (Eds.), Building Communities and Making Connections (pp. 2-15). Newcastle Upon Tyne, UK: Cambridge Scholars Publishing.

Martínez, G. \& Schwartz, A. (2012). Elevating 'low' language for high stakes: A case for critical, community-based learning in a medical Spanish for heritage learners program. Heritage Language Journal, 9(2), 37-49.

Martínez, G. \& San Martín, K. (2018). Language and power in a medical Spanish for heritage learners program: A learning by design perspective. In G. C. Zapata \& M. Lacorte (Eds.), Multiliteracies Pedagogy and Language Learning: Teaching Spanish to Heritage Speakers (pp. 107-128). New York, NY: Palgrave Macmillan.

Pino, F. (2001). A pilot project to include culture in the Spanish business language curriculum for heritage speakers. Proceedings of the Annual Meeting of the National Association of Hispanic and Latino Studies and Affiliates. Westbrook, ME: National Association of African American Studies and Affiliates.

Polinsky, M. \& Kagan, O. (2007). Heritage languages: In the 'wild' and in the classroom. Language and Linguistics Compass, 1(5), 368-395.

Ruggiero, D. (2018). Community service learning, learning by design, and heritage learners: A case study. In G. C. Zapata \& M. Lacorte (Eds.), Multiliteracies Pedagogy and Language Learning: Teaching Spanish to Heritage Speakers (pp. 129147). New York, NY: Palgrave Macmillan. 
Salgado-Robles, F. \& Kirven, L. (in press). Boosting intercultural competence in Spanish for social service professionals through service-learning. Cuadernos de ALDEEU, 33.

Sánchez-López, L. (2013). Service-learning course design for languages for specific purposes programs. Hispania, 96(2), 383-396.

Sánchez-López, L., Long, M. \& Lafford, B. A. (2017). New directions in LSP research in US higher education. In M. Long (Ed.), Languages for Specific Purposes: Trends in Curriculum Development (pp. 13-36). Washington, DC: Georgetown University Press.

Thompson, G. L. (2013). Intersection of Service and Learning: Research and Practice in the Second Language Classroom. Charlotte, NC: Information Age Publishing.

Valdés, G. (2001). Heritage language students: Profiles and possibilities. In J. K. Peyton, D. A. Ranard \& S. McGinnis (Eds.), Heritage Languages in America: Preserving a National Resource (pp. 37-77). McHenry, IL: Delta Systems Company.

\section{APPENDIX}

\section{Appendix 1: Student Survey (Adapted from Thompson, 2013)}

Your professor would like to know your opinion about the community servicelearning component of this course. The responses you provide will be used to improve the project in the future. Your participation in this survey is completely voluntary and it will take approximately ten minutes. Thank you for your participation. First, your professor would like to ask you some general questions about your community service-learning experience. Using the following scale (ranging from 'Strongly Disagree' to 'Strongly Agree'), please indicate your level of agreement with the statements below by writing the appropriate number. If a statement is not relevant, please write 0 ('Not Applicable').

0: Not Applicable

1: Strongly Disagree

2: Disagree

3: Neither Agree nor Disagree

4: Agree

5: Strongly Agree 


\section{At the beginning of the semester:}

1. I knew what community service-learning was.

2. The course objectives and how they related to the service-learning experience were clearly stated in the syllabus.

3. The course objectives and how they related to the service-learning experience were clearly communicated by the professor.

4. The course objectives and how they related to the service-learning experience were clearly communicated by the community partner(s).

5. I was eager to begin my service-learning project.

\section{Throughout the semester:}

6. The needs of the community partner(s) (i.e., school) were clearly communicated to me.

7. There was adequate communication between the cooperating teacher and me.

8. There was adequate communication between the professor and me.

9. I felt I could contact the cooperating teacher if I had concerns.

10. I felt I could contact the professor if I had concerns.

11. The cooperating teacher provided me with guidance.

12. The cooperating teacher provided me with challenging and meaningful activities.

13. I took the time to understand the needs in the classroom.

14. In my work, I addressed the classroom need(s) I identified.

15. I took this project seriously.

16. The work I did increased my understanding of the nature of teaching.

17. The work I did helped me see how the subject matter of the course can be applied to the teaching of Spanish.

18. The service aspect of this course showed me how I can become more involved in education.

19. The service aspect of this course helped me become more aware of the needs of schools.

20. The service involved in this course benefited the students and the cooperating teacher.

21. During my service I interacted with students from different social, economic, or ethnic backgrounds.

Reflecting on the course and the entire community service-learning experience:

22. The service involved in this course helped me gain a clearer idea of my goal to become a Spanish teacher. 
23. The service I performed and the skills I developed helped make me a better future teacher.

24. The service experience complemented the learning objectives of the course.

25. The time needed to satisfy the service-learning component of this course was worthwhile.

26. The service-learning experience had a direct impact on my personal growth.

27. The service-learning experience had a direct impact on my oral communication skills.

28. The service-learning experience had a direct impact on my Hispanic/Latino identity. (Please explain your answer below.)

29. The service-learning experience had a direct impact on my identity as a Spanish speaker. (Please explain your answer below.)

30. The service-learning experience helped me gain a better understanding of the needs of heritage learners. (Please explain your answer below.)

31. The service-learning experience allowed me to put into practice strategies for the teaching of Spanish to heritage learners. (Please explain your answer below.)

32. What would you suggest in order to improve this service-learning experience?

(Please explain your answer below.)

\section{*ACKNOWLEDGEMENTS}

We would like to extent our sincere gratitude to our students enrolled in a Foreign Language Teaching Methodology course. Without their participation, this study would not have been possible. Their work guided us in the redesign of the required coursework for the Spanish Adolescence Education major presented in this paper. We would also like to thank the Institute for Language Education in Transcultural Context from The Graduate Center - The City University of New York for awarding us with the Innovations in Language Education Grant, which allowed us to pilot the initial steps of this project. Lastly, we are grateful to the anonymous reviewers for their constructive feedback in earlier drafts of this article. 